University of Nebraska - Lincoln

DigitalCommons@University of Nebraska - Lincoln

June 2003

\title{
Endangered Democratic Institutions and Instrumental Inquiry: Remarks upon Receiving the Veblen-Commons Award
}

F. Gregory Hayden

University of Nebraska - Lincoln, ghayden1@unl.edu

Follow this and additional works at: https://digitalcommons.unl.edu/cbafacpub

Part of the Business Commons

Hayden, F. Gregory, "Endangered Democratic Institutions and Instrumental Inquiry: Remarks upon Receiving the Veblen-Commons Award" (2003). College of Business Faculty Publications. 10.

https://digitalcommons.unl.edu/cbafacpub/10

This Article is brought to you for free and open access by the Business, College of at DigitalCommons@University of Nebraska - Lincoln. It has been accepted for inclusion in College of Business Faculty Publications by an authorized administrator of DigitalCommons@University of Nebraska - Lincoln. 


\section{Endangered Democratic Institutions and Instrumental Inquiry: Remarks upon Receiving the Veblen-Commons Award}

\section{F. Gregory Hayden}

I want to thank the Association for this honor. I am exceedingly grateful for the award. In addition, I am exceedingly grateful for the Association for Evolutionary Economics. The Association, the Journal of Economic Issues, and the outstanding people in the Association have been very instrumental in my scholarly development.

I want to thank my wife, Theresa. She has always made a major contribution to my research and public policy activities. In addition, she has nourished my intellect and stimulated my interest through a lifetime of commentary on all subjects.

I could not begin to recognize all the institutions to which I am indebted. But I do want to recognize the land grant universities with the excellent professors and students from whom I have acquired so much. As an undergraduate I had economics professors like Robert Brazeltson, Robert Darcy, Paul Barkley, and Walter Bagley. And there could not have been a more excellent group of professors or a group more devoted to their students than were mine in graduate school-Walter Neale, Daniel Morgan, Carey Thompson, Clarence Ayres, Douglas Dacy, Stephen McDonald, F. Ray Marshall, Wendell Gordon, Forest Hill, H. H. Liebhafsky. Think about that list! How fortunate this student was! After graduate school, I joined a university where I have had great colleagues in numerous disciplines as well as in economics. The department has included institutional colleagues like Wallace Peterson, Jerry Petr, Bert Evans, James Swaney, and Ann Mari May. They have contributed immensely to my development. The excellent students at the University of Nebraska are a group from whom I have learned much and from whom I continue to learn. I have indeed been a very fortunate person.

Let me begin my comments by recounting a bit of history.

In the 1890s, British cattle companies drove large herds into the sparsely settled grasslands of Nebraska like an invading army. Immediately, the drovers started killing homesteaders, who were always shot on the homesteader's land at the plow or mower to clarify that it was the homesteading that was the capital offense. The cattle companies 
fenced public lands and paid others to file claims on their behalf, all in clear violation of the law but protected because they controlled the courts, bought political influence, and continued to intimidate. Many homesteaders refused to be intimidated. They contested the phony homesteads and testified against the companies, and some were killed because of their legal activity. The homesteaders prevailed because in 1908 President Theodore Roosevelt ordered the arrest of a leading cattle company boss for fencing public lands. The boss was let off with a small fine, after which he was treated to a champagne dinner provided by the federal marshal in Omaha, Nebraska. Roosevelt fired the marshal and replaced him with a man who enforced the law. The cattle companies were removed from the land, and individual settlers built the ranches (Charles $\mathrm{H}$. Hassebrook, Center for Rural Affairs Newsletter, September 2002).

I tell of this situation for two reasons. The first is to note the difference between the reaction against the corporations then and now. Large companies were not symbols of high status and authority to which citizens automatically deferred with a fundamental asymmetry of authority. Second, the bit of history clarifies that a major determinant of the economy is politics. My discussion today deals with issues of one kind of political system, that of democracy. Instrumentalists have a special concern for democracy. The instrumental approach developed as a result of the integration of democratic policy making and science, an integration compelled by democracy. For instrumentalism to continue to develop and to continue to successfully assist in policy making, democracy needs to be a viable institution for guiding social inquiry.

As Louis Menand wrote in his book, The Metaphysical Club, we are now experiencing a resurgence of the instrumental approach in the scientific world (2001). That resurgence is welcome! I can remember a few decades ago when the books by Marc Tool and Rollo Handy were about the only books available to the public for challenging the so-called positivism that gained popularity at the time. While instrumentalism is experiencing a resurgence, one of the core concepts of instrumental policy making is experiencing difficulty. That concept is democracy.

Due to good fortune, part of my career has been spent in the public policy arena. From that experience, I have come to realize concerns that I believe need particular attention for the continued development of instrumental policy analysis and for a viable democratic political system. Today, I would like to discuss some of the new concerns and challenges surrounding the functioning of democracy.

\section{Forming Publics in a House Divided}

The first concern is with the increasing difficulty to form a public to solve a problem or set of problems. To solve problems, it is necessary for citizens and organizations that are associated through social transactions that create and experience the direct and indirect consequences of the transactions to be organized into a public association for action. Such a public association needs to include the legislative and judicial mecha- 
nisms and procedures necessary to solve the problem. John R. Commons laid the foundation for the study of such legislative and judicial networks. The organized public needs to include both the current citizens and organizations whose transactions are creating and experiencing the problematic consequences and those who will be involved in the solution. Such a public must be organized as part of the instrumental process. A public does not organize itself automatically. Intelligence, wisdom, and scientific knowledge are needed to solve problems to include the formulation of the public association. The research necessary for the creation and application of those ingredients will not happen without an organized public to support such application, and the public will not be organized without research devoted to determining the extent of the problem and the best structure for the organization consistent with the expected consequences. John Dewey explained this seventy-five years ago, and it is one of the first lessons impressed upon me upon my entering the legislative arena because it is one of the most arduous, complex, and often impossible-but absolutely necessary-tasks in policy making. As Dewey stated: "It is not that there is no public, no large body of persons having a common interest in the consequences of social transactions. There is too much public, a public too diffused and scattered and too intricate in composition. And there are too many publics, for conjoint actions which have indirect, serious and enduring consequences are multitudinous beyond comparison, and each one of them crosses the others and generates its own group of persons especially affected with little to hold these different publics together in an integrated whole" $(1954,137)$. That was what Dewey observed in the 1920s. The task of formulating publics today is much more difficult.

The instrumental research and action for public formation has become more difficult for at least five reasons, all of which are related to advancing technology. The first four are (1) the increased rate of social disruption, (2) increased social complexity, (3) extended globalization, and (4) the more advanced level of techniques available for propaganda by organizations satisfied with the status quo and/or interested in preventing solutions. These four are well understood. Technological advancement disrupts social structures, and technology continues to advance at an accelerated rate. Social systems constantly differentiate into more complex systems, and they do so more rapidly with advancing technology. Globalization is a consequence of technology, and advancing technology has embedded most local and regional activities into a global context (see Elsner 2000) that is often unstable. And powerful organizations such as multinational corporations have encapsulated modern technology for propaganda to prevent the formation of relevant publics. These four reasons are not new but, rather, exhibit an extension and intensification of familiar difficulties.

The fifth difficulty is the evolution of growing ideological differences within the domestic political system. My experience and reading about the current political economy indicates there are now very different ideological groups within the domestic political systems, and it appears that the number of these groups will continue to grow and their differences will intensify. The ideological differences among six different major 
ideologies are explained in Mark Gerzon's A House Divided (1997). The division of the nation into numerous different systems of integrated beliefs makes it much more difficult to organize affected persons and organizations into associations to solve problems. These are not differences of interest. Groups with different interests can arrive at compromises regarding policy much more easily than those with extreme ideological differences. If the groups believe other ideologies to be illegitimate and/or that secular policy-making bodies are illegitimate, progress toward solutions is very difficult. That is today's situation. Abraham Lincoln worried that a country divided into two groups would not stand. A country divided into numerous distinct hostile ideologies cannot expect to form many associations for solving problems because problems such as disease, unemployment, and polluted water cut across ideologies.

One of the main causes for distinct differences among groups in modern society is that the social system is not structured to automatically require citizens to interact on a regular basis with those with whom they disagree. In the past, the butcher, baker, and candlestick maker interacted on a personal face-to-face basis in order to function economically and, in addition, they interacted with a variety of persons at church, in the schools, at city council meetings, at the lodges and clubs, and so forth. Today, people gravitate toward associations of least resistance and avoid unpleasant exchanges that challenge ideas and prejudices. This was not the case in the past. The social and technological system in the past was such that personal associations and exchanges were compelled. Face to face association led to discussion of ideas, beliefs, and policies that prevented multiple ideologies from developing. We learn from systems theory about the necessity for negative feedback loops to maintain system stability. The negative feedback among us is being lost. We use cell phones, computers, airplanes, telecommunications, and international conferences to limit our circle of communication. There are a "myriad solitaries perched in front of their screens and connected only by their fingertips to the new virtual web defined by the Internet. But the politics of that community has yet to be invented, and it is hardly likely to be democratic. People on the Net do prattle on about community, but when have they last spoken to a neighbor? If good fences make good neighbors, virtual neighbors make good fences-against real neighbors" (Barber 1996, 151). Modern technology has widened the social space among us and intensified political, religious, and social differences.

I recently found myself in a meeting that included two persons with Christian Bibles, a third with a Bible and a crucifix, two militia persons in camouflage fatigues, and three men who are corporate executives. They represented the conservative Christian, right-wing militia, and corporate ideologies. Each group thought the others to be misguided, immoral, and illegitimate, and all three thought our government to be illegitimate-the Christians because it is a secular government, the militia members because government is inconsistent with liberty, and the corporate executives because government regulations interfere with the economic growth and progress corporations can bring society. After the meeting, each could return to his or her own group and not have 
to deal with the ideas of the others. Deliberation melds differences. However, there is no basis for deliberation if groups become too distinctly different. Before there can be deliberation for policy making, those with differences have to, one, believe the other is worth the attention and effort to listen to and, two, have a commitment to civil society. Both are fading.

We have developed a very difficult situation with regard to forming publics for policy making. Technology not only draws us apart by specializing us into more narrowly defined occupations; it has separated us socially, and we associate less with those who hold different views outside of work. Not only do we not know the person next door, we are now able to select associations to avoid those with whom we disagree. Our technology has splintered us ideologically while drawing us closer together in terms of impacts on each other. Because farmers in the Upper Midwest of the United States use herbicides and pesticides, the fishing industry in the Gulf of Mexico thousands of miles away is destroyed. Because industry spews out noxious fumes at a higher level, emergency ward admissions for child-asthma attacks increase thousands of miles away. The policy-making dilemma is that as the technological factors multiply the impact we have on each other, society has been resolved into discrete factors. This will continue to be a challenge for forming publics and conducting democratic policy making.

\section{Corporate Symbols and the Delegitimization of Government}

The second concern is how the use of a particular symbol has assisted in the delegitimization of government and increased the power of corporations as governing institutions. The concern is with regard to the power that corporations have acquired because economists have sanctioned money flows as the measure of value in policy and program analysis. This has undermined democracy. When economists insist on the use of money flows as the dominant concern, it assists in the conversion of our system from one in which government is the dominant governing institution to one in which corporations become dominant. The ascription of price as the symbol for what is of value conveys to society that corporations as price makers and, therefore, as creators of societal value are to hold rule-making powers. This is accomplished by making the sign and symbol of the corporation the dominant sign and symbol in policy discussions and program evaluation.

Signs and symbols are the means of communication by which a socially shared experience is ushered in and sustained (Dewey 1954, 218). Dewey explained that "the symbols of the ideal engage thought and command loyalty. Symbols control sentiment and thought and, therefore, it is imperative to have the signs and symbols consistent with community interest. Without such communication, the public will be lost" (142). As Raymond Firth stated, humans do not live by symbols alone, but humans order and interpret reality by symbols and even reconstruct reality with symbols $(1973,20)$. Since symbols are essential to the processes of social organization and communication, to 
approach the study of political power "from a symbolic perspective is to recognize the peculiar problems of synchronizing diverse motivations, expectations, and values so as to make collective action possible. Symbols provide the vehicle through which that is done" (Elder and Cobb 1983, 28). Symbols help clarify both the constraints and the flow of resources available for organizations that are competing for power. "Such symbols must serve a dual purpose: they must be at once particularistic, serving to unite the group and maintain its unique identity, and universalistic, legitimizing it as an agency of power to the great majority of outsiders" (Lewellen 1983, 112). One such symbol is corporate revenue. It unites corporate members and legitimizes corporate power to citizens.

The functioning of social and economic institutions is, to a great extent, the result of responses to symbols that range from "soft" to "hard." Soft symbols are not as specifically defined nor responses to them as rigidly enforced, and, furthermore, people are allowed to manipulate soft symbols. An example of a soft symbol is the NIMBY (not in my back yard) symbol which was created by a public relations firm as part of a corporate propaganda campaign against environmentalists. Before the advertising people and lobbyists could harden it into people's minds as an insulting term against those who wanted to save the environment, the opposition adopted it in environmental campaigns against corporations. NIMBY remains soft and continues to be manipulated. Thus, it is not effective in providing for control. Hard symbols are "hardwired" into minds and social processes so that such symbols move people and resources to form socioeconomic patterns and, therefore, determine positions of status, wealth, and power.

The point I wish to make is not that corporations are devoted to pecuniary values that do not reflect industrial productivity. Thorstein Veblen explained that about a century ago. The point is not that market values are not a measure of value. That has been explained hundreds of times in the last century. The point is not that cost-benefit analysis is not legitimate for evaluating social programs. Economists from across the spectrum, as well as court decisions, have made that point numerous times. The point I wish to explain is that the hardening and hardwiring of the dominant symbol of corporations to be the dominant measure of social value and accountability is a serious problem for democracy. Economists have adopted the pecuniary prices charged by corporations as the appropriate measure of social value to be used for making social, economic, politi$\mathrm{cal}$, and ecological policy decisions. By so elevating corporate prices, the procedures, processes, and decisions of corporations are assumed to function in a manner such that their prices are legitimate symbols by which we should evaluate, design, and govern programs and social processes. It has been powerful in hardwiring the corporate symbol of price as a legitimate symbol to which societal entities respond in a manner that accommodates corporate interests and power and enhances corporate prestige. This has assisted in the demotion of democratic government as the dominant and legitimate institution for making decisions and has assisted in the promotion of corporations into that position. 
Economists argue that monetary prices are to be the common denominator. Thus, they act to utilize corporate prices as the measure of benefits, as well as costs, for the analysis and evaluation of programs, social structures, and ecological systems. Since government programs are often finalized by government payments to corporations, this means the dollar symbol is used to analyze dollar charges made by the corporation-a rather circular analysis. A flow of money is justified by an appeal to a money unit. That is like justifying E. coli-infected meat by an appeal to E. coli bacteria. It is easy to be justified as acceptable by the use of such circular reasoning. "We do not know the sign of X by the sign of X.... We know the sign of X (X' signification) by the interpretant of X" (Hayden 1995, 367). More important, however, the approach of using money to justify money creates serious political problems for public policy making because it enhances the measure used and control of analytical outcomes by those organizations whose interests, transactions, and decisions are expressed in monetary terms-that is, corporate organizations.

The adoption of price as the measure of value endows corporations with exaggerated legitimacy and power in three ways. First, in a semiotic sense, corporate symbols are elevated to serve as the standard for policy analysis, and, therefore, the legitimacy of the corporate organization is elevated. To take the symbols of one institution as the measure and purported common denominator of a complex social process alienates and demotes other symbols in the minds of citizens and policy makers. If corporate prices are elevated to serve as the value index for everything, where does it leave organizations that must determine the number of children that can be fed by a government program? Policy makers will inquire about the dollar value of feeding children. How do environmental organizations calculate the number of species that can be saved by a program that has been advocated? What is the dollar value of an endangered beetle in a South Dakota wetland? What is the dollar value of a lower lead level in children's blood? Emphasis on the monetary symbol of corporations as the correct measure shuts out the measures of other institutions. Other institutions and organizations are limited in making their case about concerns and criteria that are important to their organizations. Thus, the evaluation process serves as a negative sanction.

Second, in terms of political power, the selection of the corporation's criterion of success-that is, dollar flows-as the social criterion of success provides a definite advantage in terms of political legitimacy, standing, and power. Social programs that increase dollar flows for corporations are measured as an increase in social welfare. This makes for a positive sanction for programs attuned to the symbol.

Consider the result if any other particular flow were selected as the unitary measure of value, for example, if the energy flowing through ecological systems were made the dominant indicator. Programs would be considered more valuable if energy flows in ecological systems were increased and less valuable if decreased. Programs for all areas-from childcare to weapons-would be skewed to enhance ecological systems. Wetlands would gain the status of the mounds of ancient Mesopotamia. Such an 
approach would, of course, be as misguided as it is to select monetary flows as the determinant symbol.

Third, the selection of corporate price as the appropriate measure means the analytical apparatus of the corporation becomes the dominant model for analysis. Financial accountants of corporations, for example, are experts on corporate dollar flow, and, therefore, they possess the expertise to dominate analysis and discussion in the policy-making process. Religious leaders, welfare mothers, and ecologists, on the other hand, are not experts in financial discounting and cost accounting and, thus, are at a disadvantage in the process. How is it possible to argue for clean air to prevent asthma in children when limited to dollar flows and discounting as the criteria?

Although monetary price is not a valid conceptualization of criteria for evaluation, it has been symbolized as such, and, as such, corporate organizations which determine, receive, and pay prices are given the prestige necessary to become organizations with ruling power. If a social entity is associated with or possesses what is designated as the truth symbol in a society, that social entity stands to gain standing, respect, and power.

Of course, economists could not have accomplished all this without propagandists who promoted the same. We have heard about the glories of oligopolistic markets and prices on a regular basis from an array of persons speaking consistent with increasing corporate prestige and power. The premise of the propaganda is that corporations can replace government as the center of democracy and regulation. These persons range across the spectrum from Enron CEO Ken Lay to New York Times columnist Thomas Friedman. Friedman, for example, wrote that participation in the market amounted to popular sanction of both the processes of market exchange and the corporations involved. When such pundits have spoken of the market being democratized, "they implied that the market now functioned like a democracy; that the market represented the people, that it acted on the people's behalf, that it spoke in the vox populi" (Frank, 2000, 93). In Friedman's language, markets and exchange serve as an ongoing election booth where citizens who "vote every hour, every day" have "turned the whole world into a parliamentary system" (Friedman, 1999, 115, 142). So, according to Friedman, corporations are accustomed to performing the role of governing institutions.

As a result of the hardwiring of the corporation's monetary system as a ruling symbol, we are evolving into a system where democratic governments are becoming subordinate to corporations. Traditionally, governments made the rules and promulgated regulations for citizens and businesses in a country, and the latter were expected to comply as part of the duty and responsibility of living and doing business in that country. However, more and more, government rules are not accepted if they are not consistent with the revenue calculations of the corporations. Economic historians have explained how market institutions dominated society in the 1800s. Today the evolution is toward a situation in which corporations dominate society to include government and markets. Numerous examples could be cited. One example is the case of iron triangles and sub-governments as explained in political science literature (see Hayden, Wood, and 
Kaya 2002). Another example is chapter 11 of NAFTA (North American Free Trade Agreement), in which it is clarified that if a law by a sovereign state diminishes the monetary flow expected by corporations, the law is not legal. Again and again, the corporation trumps the state, which has lost symbolic authority and, consequently, has lost sovereignty to the corporations.

\section{Analysis along the Fracture Line of Clashing Civilizations}

The third concern deals with analysis along the fracture line of clashing civilizations. The problems for democracy explained above relate to the Western societal context. For much of the world, modeling and analysis must be completed without the benefit of democracy. A major context to be recognized with regard to all problems is what Samuel Huntington termed the "clash of civilizations" in his 1997 book by the same name. Huntington explained that the world is made up of a number of very different cultures with their accompanying social beliefs and institutions that make for different civilizations. The civilizations will continue to be different, and we can expect the spread of trade and modern communications will continue to increase differences and, in some cases, increase hostilities among the civilizations. Computer enthusiasts have claimed that connectivity would lead to homogeneity; however, communication has increased differences.

Three civilizations that will continue to command the world's attention and resources as they continue to clash are the Western, Sinic, and Islamic. Their dominant characteristics will lead the people who belong to the different civilizations to be infuriated with each other, to continue to want to dominate, and, in some cases, annilhiliate each other, and, therefore, to continue to have to deal with each other up close and in a hostile context. For example, there are 1,400 years of history to document this hostile relationship between the Islamic and Western civilizations.

The West is committed to universalism. This means that all societies are to be the same; that they are to think and live like Western people and share the same assumptions, doctrines, and beliefs; and, in addition, that it is the job of the West to spread the universal civilization to others. Western universalism is expressed across many spectrums. "Karl Marx and John Stuart Mill believed that modern societies throughout the world would become replicas of western societies. . . . Modernity and the evolution of a single-world civilization were one and the same" (Gray 1998, 195). Joseph Schumpeter, of course, believed that destruction from capitalist innovation and expansion would lead to creative results irrespective of religion or philosophy. Similar views are common in newspaper opinion pages. In a column in the Omaha World Herald, Michael Berliner stated: "The values of Western Civilization are values for all men; they cut across gender, ethnicity and geography. We should honor Western civilization . . . because it is the objectively superior culture" (October 4, 2002). In the Wall Street Journal, Robert L. Bartley, who has been the editor for the last thirty years, wrote: "I look forward to the 
U.S. constructing a new, and ultimately more serious, world order" (November 20, 2002). Thomas Friedman recently expressed this Western ideal in his New York Times column as follows: "More than at any time in history, the world has come to accept the Western values of peace, democracy and free markets-around which American society is organized.... Free markets are the best way for nations to grow from poverty to prosperity" (September 15, 2002). Outside the West, Friedman's ideal civilization "is probably shared by less than 50 million people or 1 percent of the world's population and perhaps by as few as one-tenth of 1 percent of the world's population" (Huntington 1997, 57). "What is universalism to the West is imperialism to the rest" (184). It is most important for the West "to recognize that Western intervention in the affairs of other civilizations is probably the single most dangerous source of instability and potential global conflict in a multicivilizational world" (312).

The Sinic civilization dates back to at least 1500 B.C. and includes the culture of Chinese communities in Southeast Asia outside of China as well as in Vietnam and Korea. Its assertiveness is well recognized as well as its recent increase in power, which has made East Asians less hesitant to emphasize the distinctiveness and superiority of their beliefs and way of life. Their growth in economic power was significant in the second half of the twentieth century-a modernization without Westernization. "Asians believe this economic success is largely a product of Asian culture which is superior to that of the West, which is culturally and socially decadent" (Huntington 1997, 107). The economic development increases Chinese influence in the region and its ability to pursue its traditional assertiveness in East Asia. This in turn increases the probability of conflict with other civilizations in the region that will involve the United States (218).

Islam, to include Arab, Turkic, Persian, and Malay, exhibits a militancy and intolerance that includes a hostility toward Western liberal concepts. Islamic "images of the West as arrogant, materialistic, repressive, brutal, and decadent are held not only by fundamentalist imans but also by those whom many in the West would consider their natural allies and supporters" (Huntington 1997, 214). Western individualism and free speech rights receive special condemnation. Islamic people emphasize that they have a different history and different civilization and will have a different future.

Muslim militancy and challenges stem "in considerable measure from social organization and population.... Population growth in Muslim countries, and particularly the expansion of the fifteen- to twenty-four-year-old age cohort provides recruits for fundamentalism, terrorism, insurgency and migration” (Huntington 1997, 102-103).

In addition to geopolitical policy concerns, four reasons the clash of civilizations thesis is important are as follows.

First, Huntington's work demonstrates the analytical power gained when analysts utilize the conceptual distinction between culture and society. Huntington's findings are the result of an astute application of the distinction. Since at least the 1920s, the social science literature, especially in anthropology, has emphasized the difference between culture and society. The two are connected but different. Culture is the center, 
and severe problems are created when cultural values cannot be expressed in the social institutions or, in some cases, when the cultural values of other cultures are forced on a society. Yet social scientists, especially economists, often fail to apply the distinction in their analyses. Thus, one reason for the importance of the clash thesis is because it applies and demonstrates the importance of this theoretical construct. Generally speaking, all social science analysis should do the same.

Second, since we can expect constant conflicts among the three major civilizations, especially along fracture lines, dependence on war and violence to solve the conflicts makes no sense. The differences cannot be resolved. They are cultural, and to the extent that cultures evolve, it is a matter of centuries and not within the real-time context of current problems. From a defense point of view, it makes no sense to squander economic resources and human lives for military endeavors that will not resolve the problem of cultural conflict.

It is important that the United States reaffirms its commitment to Western civilization, especially to democracy and instrumental science, if we want to survive, but Western universalism as now expressed is dangerous to the West and to the world because it could lead to major war and possibly to the defeat of the West. The West can be weakened by the drain on its resources brought about by war and by the loss of strategic resources and production from other parts of the world. In addition, it can be weakened by an inability to solve global problems through intercivilizational negotiations during war. For example, many ecological problems are global, and a failure to solve them is costly to the West. Thus, the precautionary approach is to avoid turning to a policy of warfare because the cooperative processes necessary to solve problems will be destroyed without positive benefit.

Third, the alternative to war is prevention through negotiations, agreements, regular inspections, and police actions conducted with major states of other civilizations. Western universalism should take the form of providing leadership in establishing means to bring about negotiations to establish cooperation and enforcement of negotiated agreements. It is not necessary to love one's neighbor in order to establish mutually beneficial agreements.

Fourth, massive studies will be needed to decide how to solve intercivilizational problems before negotiated solutions can be successful. This creates a problem because democracy is not available in much of the world and because analysis is weakened when democracy is not available to guide scientific work, especially in the policy sciences. For example, what is to compel Western scientists to be honest and explicit about program consequences that will take place in other civilizations? Democracy brings the community into the analysis process. "Thinking is a social activity" (Menand 2001, 431). Without democracy and free expression represented in part of the intercivilizational community, thinking and analysis will suffer. A "critical aspect of political process is the role it plays in determining the standards of judgment by which behavior is correlated throughout the institutional structure of society" (Tool and Bush 2002, 31). That includes scientific behavior and judgment and the institutional structure for research. 
"The institutional arrangements through which the polity addresses these questions represent some of the heaviest burdens carried by the political process in a democracy" (31). This means special efforts and oversight committees are going to need to be established to consider the normative criteria of all groups involved when research is conducted. Much of the task will fall to Western oversight procedures-not to fulfill universalist predilections for expansion but because democratic institutions from other civilizations are not available. Western democracy must monitor and critique intercivilizational research to keep it relevant and instrumental. This is another reason to get our own democratic house in order.

\section{Rules Selection Divorced from Social System Criteria}

My last concern is about an antidemocratic paradigm developing within the West. Currently, the most active intellectual challenge to democracy is from the ideology that is an integration of the new institutional economics and public choice (NIEPC). Those promoting this paradigm are candid about wanting a system of political and economic intolerance wherein a comprehensive doctrine and its rules are imposed that cannot be changed. These are not to be rules designed to enforce societal beliefs, nor are they to be rules derived from democratic processes. As explicitly stated, "constitutional political economy concerns the legal foundations of the market" (Mudambi et al. 2001, 1). Their rules and regulations are to function to place constraints on persons and on social and political action. Their rules are the rules of the competitive market system, with neither recognition of the historical record of the harm done when the market system did gain dominance over other institutions nor recognition of the growing number of police that would be necessary for the authoritarian government to field in order to constrain protests of a citizenry with a civic tradition, once the suffering begins. Numerous economists have clarified why and how the dictates of an encompassing market system leads to human suffering, ecological damage, and resource waste. As Karl Polanyi explained, "The congenital weakness of nineteenth century society was not that it was industrial but that it was a market society" $(1957,250)$.

The NIEPC approach is quite inconsistent with democracy. It emphasizes the enforcement of rules and procedures of a particular system, while democracy is committed to changing rules and procedures to achieve desirable consequences. Democratic justice requires that citizens have the right to change rules and procedures of the institutional structure-to participate in deciding what kinds of institutions are to be approved. Justice is not realized just because the allowable context of prescribed rules and regulations is followed. The establishment of a state to adhere to predetermined axiomatic rules "challenges conventional pluralist understandings of policymaking, which emphasize the impact that citizens are to have on policymakers, rather than the effect the state is to have on citizens" (McAvoy 1994, 727). According to NIEPC, an advantage of rigid formal rules that citizens cannot change is that such rules "will require institutions that 
permit agents to know about successively smaller factions of the larger social environment" (Heiner 1983, 115) and "enable each agent in the society to know less and less about the behavior of other agents and about the complex interdependences generated by their interaction" (116). In other words, it is NIEPC's goal for citizens to become more and more ignorant about the complex system upon which citizen welfare depends.

Many of the NIEPC conclusions and recommendations are based on the adoption of methodological errors that are inconsistent with modern science.

First, they define institutions as bundles of rules. This simple definition of institutions ignores the complexity of reality for the purpose of recommending a simple predetermined set of rules contrary to democracy (or other political forms). Rules are part of institutions, but institutions are much more. They are patterns of activities, flows, and deliveries in complex open systems that fulfill belief criteria and coordinate beliefs, technology, ecological entities, attitudes, and the overlapping spheres of different institutions themselves.

Second, neither the important distinction between culture and society nor the distinctions among values, beliefs, and attitudes are maintained in their methodological approach. As stated above, culture is central, and it is not an expression of markets or a market system. An attempt is made by NIEPC to demote the methodological importance of culture in order to ignore any given cultural prescription to which market institutions are to be subordinate. It is an attempt to assume away a group's culture in order to resolve the subordination found in reality. In fact, NIEPC ends up conceptualizing culture merely as policy or as the arena of competing ideologies in an institutional context.

Likewise, attitudes which are subordinate responses in institutions are elevated by NIEPC to be expressions of social beliefs and cultural values. It is an insult to a civilization to assume that its culture and society are so shallow and weak that they are expressed and can be changed by what the attitudes are toward market items like soft drinks and neckties. Buying in the marketplace can be an ingredient in the expression of some particular social beliefs. Such buying does not inform about what social beliefs ought to be.

Normative criteria exist in reality and are necessary in order to decide what rules and procedures should be implemented in institutional processes. "To realize justice in its fullest sense-as encompassing outcomes as well as procedures and societal as well as individual considerations-it seems that a shared conception of the good is necessary" (English 1991, 9), as are the criteria to articulate the good. NIEPC avoids criteria because such consideration opens discussion about what the good ought to be. Instead, it wants to dictate rules consistent with the market. However, before rules make any sense, they need to be consistent with social norms (see Hayden 1998).

Third, NIEPC defines democracy as a marketplace for individual exchanges and, tautologically, states that marketplace rules and regulations should constrain individuals to conduct exchanges as in a marketplace. Michael Ensley and Michael Munger were 
explicit that when outcomes differ from what society considers good, it does not mean the market organizations are not optimal $(2001,109)$. This view is obviously inconsistent with democracy.

Fourth, NIEPC adopts a Darwinian concept of evolution-the concept that individuals of a species improve with continuous variation and selective retention by an environment in which competition reigns. This allows NIEPC (1) to argue for a fierce competitive milieu, (2) to claim that survival indicates the most fit have survived because, tautologically, only the fit survive, and (3) to argue against policies to protect people and institutions as provided through democratic processes.

The adoption of this kind of Darwinian model of evolution is inconsistent with the social sciences in general and instrumental institutionalism in particular. Problems with trying to adopt Darwinian models of evolution include the following:

- Social scientists do not use theories like Darwin's. Social systems do not change because mama and papa social systems beget broods of varying daughter social systems.

- With Darwin, species varied to better fit a niche in the environment. With social systems, variation changes the environment.

- New technology which is a major source of social change is not innovated and implemented by accident as is the argument for Darwinian mutation. The innovation of new technology is the result of decisions made in and deliberate action taken by social institutions. The new innovations do not fit a niche in the environment; they change the environment.

- Social systems are not limited to one source of change as was the case in Darwin's system. Social change can come from a multitude of sources.

- Darwin believed that biological entities adapted with new variations to the slightest change in the environment while we are aware that beliefs, cultures, attitudes, and institutions can be past bound and resistant to change even when circumstances have changed drastically.

- Improvements to species, according to Darwin, arise due to an unconscious competition among individuals to leave more of their genes in surviving offspring. Improvements in social systems arise as a result of conscious collective decisions made in social institutions.

Although the recommendations of NIEPC are inconsistent with history and science, its researchers are well funded and ideologically committed; therefore, we can expect continued efforts by this group to replace constitutions committed to democracy. 


\section{Conclusion}

Let me conclude by emphasizing that the task we face in order to restore and maintain the democratic component for scientific research, policy, and social progress will be daunting. "Holmes, James, Peirce, and Dewey wished to bring ideas and principles and beliefs down to a human level because they wished to avoid the violence they saw hidden in abstractions" (Menand 2001, 440). Those scholars, along with Veblen and Commons, were developing the scientific paradigm upon which we are dependent at the same time Theodore Roosevelt was saving the small ranchers in Nebraska. Both sets of activities were dependent upon democracy. The restoration and maintenance of democracy is necessary in order to continue the progress initiated by our intellectual and political ancestors. We can continue to build on their base with the pursuit of concrete analysis of current problems with democratic guidance.

\section{References}

Barber, Benjamin R. Jihad ws. McWorld. New York: Ballantine Books, 1996.

Dewey, John. The Public and Its Problem. 1927. Reprint, Chicago: Swallow Press, 1954.

Elder, Charles D., and Roger W. Cobb. The Political Uses of Symbols. New York: Longman, 1983.

Elsner, Wolfram. "An Industrial Policy Agenda 2000 and Beyond: Experience, Theory, and Policy." In Industrial Policies after 2000, edited by Wolfram Elsner and John Groenwegen, 411-486. Boston: Kluwer Academic Publishers, 2000.

English, Mary. “Siting, Justice, and Conceptions of the Good.” Public Affairs Quarterly 5 (January 1991): 1-17.

Ensley, Michael J., and Michael C. Munger. "Ideological Competition and Institutions: Why 'Cultural' Explanations of Development Patterns Are Not Nonsence." In Rules and Reasons: Perspectives on Constitutional Political Economy, edited by Ram Mudambi, Pietro Navarra, and Giaseppe Sobbrio, 107-121. Cambridge: Cambridge University Press, 2001.

Firth, Raymond. Symbols: Public and Private. Ithaca, N.Y.: Cornell University Press, 1973.

Frank, Thomas. One Market under God. New York: Doubleday, 2000.

Friedman, Thomas L. The Lexus and the Olive Tree: Understanding Globalization. New York: Farrar, Straus and Giroux, 1999.

Gerzon, Mark. A House Divided. New York: Penguin Putnam Inc., 1997.

Gray, John. False Dawn: The Delusions of Global Capitalism. New York: The New Press, 1998.

Hayden, F. Gregory. "Instrumentalist Policymaking: Policy Criteria in a Transactional Context." Journal of Economic Issues 29 (June 1995): 361-384.

"Normative Analysis of Instituted Processes." In Institutionalist Theory and Application: Essays in Honor of Paul Dale Bush, edited by Susan Fayazmanesh and Marc R. Tool, 89-107. Northampton, Mass.: Edward Elgar, 1998.

Hayden, F. Gregory, Kellee R. Wood, and Asuman Kaya. "The Use of Power Blocs of Integrated Corporate Directorships to Articulate a Power Structure: Case Study and Research Recommendations." Journal of Economic Issues 36, no. 3 (September 2002): 671-705.

Heiner, Ronald. "On the Orgins of Predictable Behavior." American Economic Review 73 (September 1983): 560-95. Quoted in Michael J. Ensley and Michael C. Munger, "Ideological Competition and Institutions: Why 'Cultural' Explanations of Development Patterns Are Not Nonsence." In Rules and Reasons: Perspectives on Constitutional Political Economy, edited by Ram Mudambi, Pietro Navarra, and Giaseppe Sobbrio, 107-121. Cambridge: Cambridge University Press, 2001.

Huntington, Samuel P. The Clash of Civilizations and the Remaking of World Order. New York: Touchstone, 1997. 
Lewellen, Ted C. Political Anthropology. South Hadley, Mass.: Bergin \& Garvey Publishers, Inc., 1983.

McAvoy, Gregory E. "State Autonomy and Democratic Accountability: The Politics of Hazardous Waste Policy." Polity 27 (summer 1994): 699-728.

Menand, Louis. The Metaphysical Club. New York: Farrar, Straus and Giroux, 2001.

Mudambe, Ram, Rietro Navarva, and Giuseppe Scobbrio. "Constitutional Issues in Modern Democracies." In Rules and Reasons: Perspectives on Constitutional Political Economy, edited by Ram Mudambi, Pietro Navarra, and Giaseppe Sobbrio, 1-8. Cambridge: Cambridge University Press, 2001.

Polanyi, Karl. The Great Transformation. 1944. Reprint, Boston: Beacon Press, 1957.

Tool, Marc R., and Paul Dale Bush. "Foundational Concepts for Institutional Policy Making." In Institutional Analysis and Economic Policy, edited by Marc R. Tool and Paul Dale Bush, 1-46. Boston: Kluwer Academic Publishers, 2003. 